Copyright by the Ecological Society of America. Lori A. Blanc and Jeffrey R. Walters 2008. CAVITY EXCAVATION AND ENLARGEMENT AS MECHANISMS FOR INDIRECT INTERACTIONS IN AN AVIAN COMMUNITY. Ecology 89:506-514. http:// $\mathrm{dx}$.doi.org/10.1890/07-0219.1

\title{
CAVITY EXCAVATION AND ENLARGEMENT AS MECHANISMS FOR INDIRECT INTERACTIONS IN AN AVIAN COMMUNITY
}

\author{
Lori A. BLANC ${ }^{1}$ AND JefFrey R. WALters \\ Department of Biological Sciences, Virginia Polytechnic Institute and State University, Blacksburg, Virginia 24061-0406 USA
}

\begin{abstract}
Direct and indirect species interactions within ecological communities may play a strong role in influencing or maintaining community structure. Complex community interactions pose a major challenge to predicting ecosystem responses to environmental change because predictive frameworks require identification of mechanisms by which community interactions arise. Cavity-nesting communities are well suited for mechanistic studies of species interactions because cavity nesters interact through the creation of and competition for cavity-nest sites. In this study, we use a cavity-nest web as a predictive framework for identifying potential indirect species interactions within a cavity-nesting community. From 2002 to 2005, we monitored abundance and nests of cavity-nesting birds in the longleaf pine (Pinus palustris) ecosystem. Using a nest-web approach, we identified a potential indirect interaction between the Red-cockaded Woodpecker (Picoides borealis) and large secondary cavity nesters, mediated by the Northern Flicker (Colaptes auratus). We used structural equation modeling to test a path model of this interaction, using cavity excavation and enlargement as mechanisms which drive the relationship between these species. Through experimental manipulation of cavity availability, we blocked links described in our model, confirming cavity creation and enlargement as processes that influence community structure. We found that a single-species management technique could potentially disrupt this indirect relationship by affecting Northern Flicker cavity-excavation behavior. This study is the first demonstration of how experimental cavity manipulation can be used to test inferred processes derived from a nest web and highlights the need to understand how mechanisms underlying species interactions can complicate ecosystem responses to environmental change.
\end{abstract}

Key words: cavity nester; Colaptes auratus; community structure; Eglin Air Force Base; indirect interactions; longleaf pine; Pinus palustris; nest web; Northern Flicker; Picoides borealis; Red-cockaded Woodpecker; structural equation modeling.

\section{INTRODUCTION}

Ecological communities consist of assemblages of species that interact with each other and the abiotic environment. These interactions occur with varying degrees of complexity and can play a strong role in influencing community structure (Krebs 1994). The need to develop a better understanding of how species interactions affect community structure has received increasing attention with the growing need to predict future impacts of environmental change on species and their associated ecosystems (Kareiva et al. 1993, Stachowicz 2001, Wootton 2002, Parmesan and Yohe 2003, Soulé et al. 2003, Parmesan and Galbraith 2004). Currently, a major challenge is to develop predictive frameworks for complex ecosystems, particularly when there is potential for indirect species interactions and unanticipated indirect effects of environmental change (Walther et al. 2002, Wootton 2002, Burns et al. 2003, Parmesan and Galbraith 2004). Indirect interactions occur among three or more species, where a species can,

Manuscript received 8 February 2007; revised 25 June 2007; accepted 2 July 2007. Corresponding Editor: R. Greenberg.

${ }^{1}$ E-mail: lblanc@vt.edu through a direct interaction with one species, indirectly affect the abundance of another species that it does not interact with directly. Many studies have documented examples of these effects in different systems (Strauss 1991, Wootton 1993, 1994a, b, 2002, Menge 1995), but still little is known about the relative importance of indirect effects in structuring communities, particularly in terrestrial systems. An important next step to understanding complex community interactions is to document mechanisms or processes by which indirect effects arise.

Cavity-nesting communities interact through the creation of and competition for cavity nest sites (Martin and Eadie 1999). These communities consist of a hierarchy of tree resources, cavity excavators, and secondary cavity users, forming a type of interaction web (Paine 1980) structured by cavity resource availability. Thus, cavity creation and subsequent use may serve as a mechanism through which indirect interactions can arise within cavity-nesting communities. In recent years, cavity excavation has been proposed as a potential keystone process within forest communities (Bednarz et al. 2004). Cavity-nesting community structure and the connections within these communities can be visualized with the use of a theoretical framework 
based on empirical data, called a nest web (Martin and Eadie 1999), which can be used to identify the species and links that are most influential in the dynamics of community composition or structure. One advantage of visualizing the community as a web is that it provides a predictive framework for identifying potential direct and indirect species interactions (Blanc and Walters 2007).

In this study, we use a combination of nest-web development, structural equation modeling (SEM), and experimental manipulation to examine interactions between the federally endangered Red-cockaded Woodpecker (Picoides borealis) and other cavity-nesting birds of a fire-maintained longleaf pine (Pinus palustris) ecosystem. SEM is a powerful statistical tool that enables the investigation of a priori hypotheses about interactions between complex systems of variables (Kline 1998, Grace 2006). Of particular use to studies in community ecology is the ability of SEM to evaluate path models, which can be used to represent direct and indirect relationships between multiple species (Grace and Pugesek 1998, Pugesek and Grace 1998). Indeed, SEM is especially well suited for studies of cavity-nesting communities because a key mechanism that structures these communities, cavity creation, may be measured and experimentally manipulated.

Fire-maintained longleaf pine forests are dominated by living pine, with relatively few snags (i.e., dead trees) or hardwoods due to the historically low tree density and influence of regularly occurring fire on the landscape (Conner et al. 2001). Current forest management practices such as snag removal and short harvest rotations further reduce snag availability. Subsequently, suitable excavation sites for most woodpeckers can be limited in fire-maintained southern pine forests of the United States. The Red-cockaded Woodpecker is the only species in this forest system that excavates nest cavities in the most abundant substrate in this system, living pine. The regular use of Red-cockaded Woodpecker cavities by other species creates the potential for direct and indirect interactions between the Redcockaded Woodpecker and other cavity nesters. Over 27 vertebrate species are known to use Red-cockaded Woodpecker cavities, and thus, the Red-cockaded Woodpecker has been referred to as a keystone species within fire-maintained southern U.S. pine forests (USFWS 2003). Usurpation and use of these cavities by other species has been well documented; however, the relationship of the Red-cockaded Woodpecker with other cavity-nesting species is poorly understood (USFWS 2003; but see Blanc and Walters 2008). Enlarged Red-cockaded Woodpecker cavities provide nesting habitat required by large secondary cavity nesters, particularly in fire-maintained areas that have few large hardwoods and snags. Species known to enlarge Red-cockaded Woodpecker cavity entrances include the Northern Flicker (Colaptes auratus) and Pileated Woodpecker (Drycopus pileatus; USFWS 2003). This process of cavity enlargement provides a mecha- nism for indirect interactions between Red-cockaded Woodpeckers and large secondary cavity nesters, mediated by other woodpecker species. While cavity enlargement may benefit secondary cavity nesters, it is often considered detrimental for the Red-cockaded Woodpecker, which will abandon greatly enlarged cavities (USFWS 2003).

Both ecosystem and single-species techniques are heavily used for managing Red-cockaded Woodpecker populations. Single-species management focuses on the creation of Red-cockaded Woodpecker cavities in living pine (Copeyon 1990, Allen 1991, Copeyon et al. 1991) and the repair and prevention of Red-cockaded Woodpecker cavity enlargement using metal restrictor plates over the entrances of the cavities (Carter et al. 1989). Red-cockaded Woodpecker ecosystem management benefits many fauna and flora of the longleaf pine community (Conner et al. 2001, 2002, Litt et al. 2001, Provencher et al. 2001, Allen et al. 2006); however, little is known about the effects of Red-cockaded Woodpecker cavity management on other cavity users. In recent years, there has been increasing focus on incorporating community interactions into Red-cockaded Woodpecker management (Kappes 2004) and concern about potential impacts of metal restrictor plates on secondary cavity nesters that use enlarged Red-cockaded Woodpecker (USFWS 2003). Studies of impacts of restrictor plates on the Red-cockaded Woodpecker have been conducted (Raulston et al. 1996, Wood et al. 2000, Walters et al. 2004); however, no studies have examined the impacts of restrictor plates on other species.

For the purpose of clarity and flow, we present this study in two parts. In part 1 , we use a nest web to visualize potential direct and indirect interactions within the cavity-nesting community of a longleaf pine forest. We then use structural equation modeling to assess a path model of relationships identified in the nest web. In part 2, we use the experimental application of Redcockaded Woodpecker cavity restrictor plates to test links within the path model.

\section{PART 1: \\ Nest Webs and Structural Equation Modeling}

\section{Study site and methods}

We conducted this study at Eglin Air Force Base, the largest forested military reservation in North America (187555 ha). Eglin, located in the western Florida panhandle, contains a large number of old-growth longleaf pine and over 6000 live and dead Red-cockaded Woodpecker cavity trees. During the study period, Eglin had an atypically high number of large pine snags due to tree mortality from the reintroduction of fire after many years of fire suppression (Varner and Kush 2001, Varner et al. 2005). Seventy-eight percent of Eglin's reservation consists of the Sandhills ecotype (McWhite et al. 1999), characterized by scattered longleaf pine, with an open to sparse mid-story of turkey oak (Quercus laevis) and a ground cover of various fire-adapted forbs and grasses 


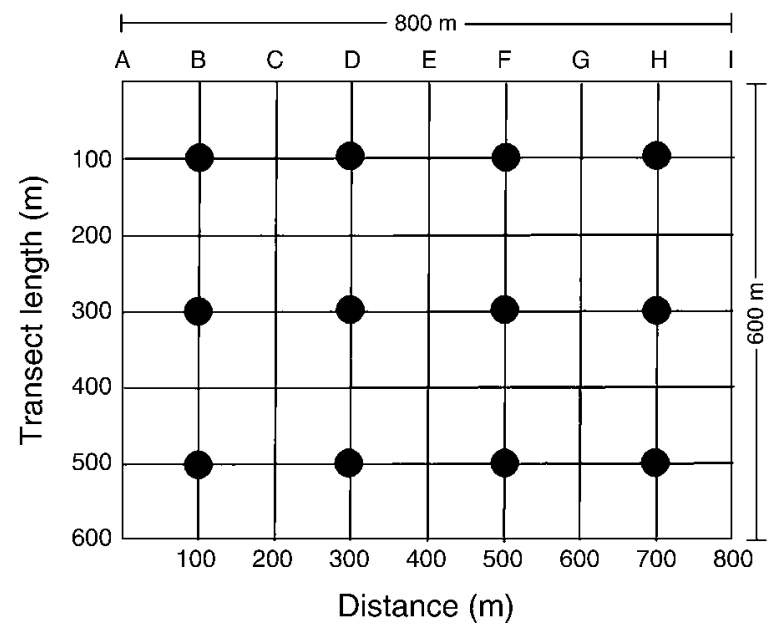

FIG. 1. Diagram showing the layout of a research plot for the cavity-nester study on Eglin Air Force Base, Florida, USA. Nine transects (labeled A-I), each $600 \mathrm{~m}$ in length, are spaced $100 \mathrm{~m}$ apart. Twelve census stations (indicated by black circles) are located on alternating transects, spaced $200 \mathrm{~m}$ apart.

(Kindell et al. 1997). Given the size of the reservation, Eglin is well-suited for large-scale studies which would require replicate plots within longleaf communities, such as the study presented here.

In April 2002, we established $36800 \times 600 \mathrm{~m}$ research plots at Eglin (Fig. 1). We restricted plots to areas within the sandhills ecotype which contained mature pine and a relatively open midstory. Within each plot, we established a grid system to aid with navigation and relocation of nests and designated 12 census stations at 200-m intervals along alternating transects (Fig. 1). Census stations were considered subsamples within each plot and each plot was a sampling unit. We acquired the locations of all Red-cockaded Woodpecker cavity trees from Eglin's long-term management data set, which was updated annually through surveys and intensive yearround Red-cockaded Woodpecker population management. Each plot contained between 0 and 43 Redcockaded Woodpecker cavities and a range of snag densities.

We used a point transect count census technique, adapted for the open habitat at Eglin, to record the relative abundance of cavity-nesting birds within each plot between 8 April and 21 June of 2002-2005 (Provencher et al. 2002). Each year, we conducted two rounds of censusing on two plots per morning within three hours after sunrise (totaling 24 census stations). Censuses consisted of 8-min point counts at each sampling station during which we recorded species, time detected, vocalization type, location, and movement within a $100 \mathrm{~m}$ fixed radius from the point center (Hutto et al. 1986). Counts included birds detected while moving between adjacent stations. Two observers censused simultaneously at stations on alternating transects (Fig. 1), and synchronized start-times for the point counts. Birds detected by both observers were not double-counted. This transect count addition to the censusing accounted for birds fleeing ahead of the observers and is considered appropriate for open habitat (Bibby et al. 1992). We calculated relative abundance by summing the detections at each census station within a plot for each round and then averaging the detections across the two sampling rounds. Our measurement was used as an index of abundance across years, rather than an attempt to quantify breeding densities.

In 2002, we conducted nest searches on all plots opportunistically. We located nests in Red-cockaded Woodpecker cavities by inspecting all cavities within each plot at least once between 15 April and 30 June. We located nests in snags by walking along transects in each plot, inspecting snags for potential nest cavities and observing breeding-bird behavior. We examined cavity contents with a camera mounted atop a telescoping pole (Sandpiper Technologies, Manteca, California, USA), which enabled access to cavities up to $15 \mathrm{~m}$ in height. To ensure equal amount of search effort on each plot, we adopted a more systematic nest-searching schedule from 2003 to 2005. We conducted two rounds of nest searching per year in each plot between 15 April and 30 June, and during each round, one crew focused on Red-cockaded Woodpecker cavities and a second crew focused on snags. During each round of nest searching, we searched for snag nests on two plots per day, with two observers simultaneously, beginning at sunrise. Each observer spent six hours nest-searching in each plot, totaling 12 person-hours per plot during each field season. We inspected the contents of all Red-cockaded Woodpecker cavities once during each round of nest searching. For each of the two rounds of sampling, we randomly determined the order in which plots were censused and searched for nests and modified this schedule when necessary for obtaining access to restricted areas on Eglin. To minimize systematic detection biases, we rotated observer assignment to transects within each plot across the two rounds.

In July of each year, we measured snag availability within 25-m radius vegetation plots, established at the 12 census stations within each research plot. We defined snags as dead, standing trees $\geq 1.4 \mathrm{~m}$ tall and $\geq 10.2 \mathrm{~cm}$ in diameter at breast height (dbh). We recorded the number and dbh of snags within each vegetation plot, classified by pine or hardwood. To calculate snag availability within a research plot each year, we summed stem data across all 12 sampling stations within the plot.

We constructed a nest web using all nest cavities found from 2002 to 2005 for which we could identify the excavator $(n=733)$ through known use of the cavity or reasonable estimation based on cavity characteristics. We included reuse of the same cavity across years, but excluded renesting attempts in the same cavity within the same year. We then developed a path model to depict relationships identified in the nest web. Because systematic nest-searching protocol began in 2003, we 
Secondary cavity nesters

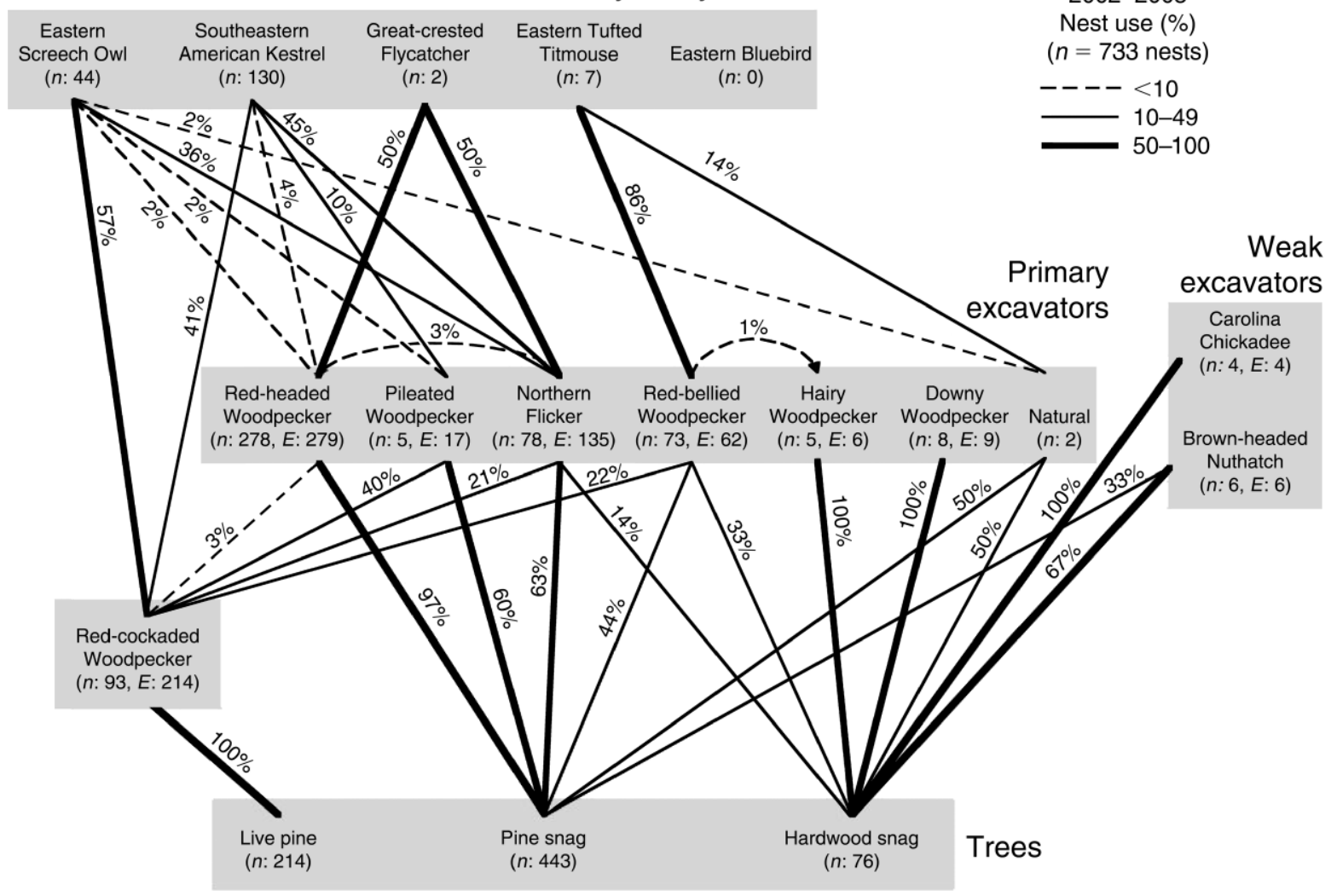

FIG. 2. A nest-web diagram highlighting the flow of cavity creation and use within the cavity-nesting bird community at Eglin Air Force Base, Florida, USA. For each species, $n$ indicates the number of nests found; $E$ indicates the total number of nest cavities excavated by that species. Line types correspond to different ranges of nest use. Links between the secondary cavity nester (SCN) level and the primary excavator (PCE) level represent the percentage of SCN nests found in a cavity that was excavated by the indicated PCE. Links between the PCE and tree level show the percentage of PCE nests found in that tree resource. The link between Northern Flicker (Colaptes auratus; NOFL) and Red-headed Woodpecker (Melanerpes erythrocephalus; RHWO) indicates that $3 \%$ of NOFL nests were found in cavities originally excavated by an RHWO. This nest web is a two-year extension of that presented in Blanc and Walters (2008).

used only data from 2003 to 2005 in the path model. Observational units consisted of each research plot from each year $(n=92)$, excluding plots with experimental manipulations from the concurrent study on large cavity availability ( $n=16$, see part 2 below).

We developed and tested our path model using AMOS (v. 5.0, SPSS, Chicago, Illinois, USA), which uses maximum likelihood to examine the overall model fit of to the observed variance-covariance matrix. We $\log$ transformed the data to meet assumptions of normality and linear relationships, and assessed model fit using a chi-square analysis (significant at $P<0.05$ ) and root mean square error approximation (RMSEA, significant at $P<0.05$ ). We also used the comparative fit index (CFI; Bentler 1990), which assesses the improvement of model fit over the fit of the "null" or independence model (generally acceptable at CFI > 0.90), and Akaike information criterion (AIC; Akaike 1987), which factors in the degree of model parsimony.

\section{Results: nest web and path modeling}

Our nest web indicates several key relationships within the cavity-nesting community at Eglin (Fig. 2). The primary creator of large cavities at Eglin was the Northern Flicker, which excavated cavities in snags and enlarged Red-cockaded Woodpecker cavities in living pine. The primary users of large cavities were the southeastern American Kestrel (Falco sparverius paulus) and Eastern Screech-Owl (Otus asio), both large secondary cavity nesters (see Plate 1). Approximately half of large secondary cavity-nester nests were found in Red-cockaded Woodpecker cavities and half were found in cavities in large pine snags ( $\mathrm{dbh}>20 \mathrm{~cm}$ ), the majority of which were excavated by the Northern Flicker. Our nest web indicates a relationship between pine snags, Red-cockaded Woodpecker cavities, Northern Flicker cavities, and large secondary cavity nesters.

Our path model is a conceptual model depicting the role that Red-cockaded Woodpecker and Northern Flicker cavities play in creating nesting habitat for large 


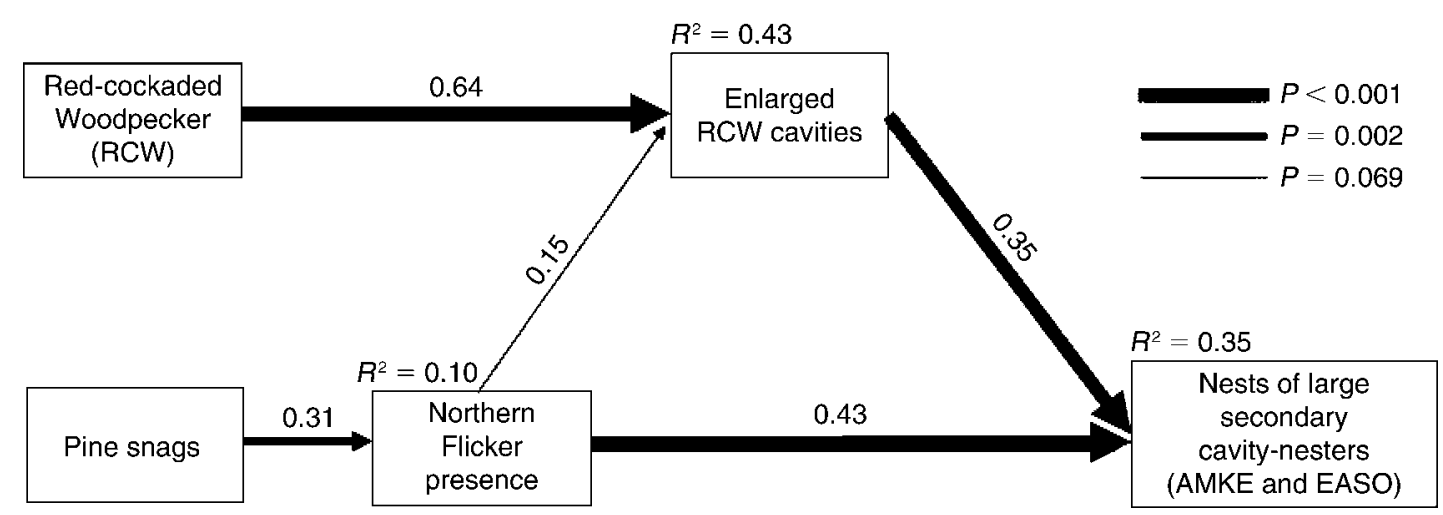

FIG. 3. A conceptual path model depicting the relationships among Red-cockaded Woodpecker (RCW) cavities, pine snags, the Northern Flicker, and large secondary cavity nesters (LSN). LSNs include the southeastern American Kestrel (AMKE) and the Eastern Screech-Owl (EASO). Arrows in the model reflect hypotheses about causal relationships between variables. Numbers above each arrow indicate the standardized partial regression coefficient showing the direct effect of an independent variable on the adjacent dependent variable in the model; line thicknesses indicate significance levels. This model fit the observed data $\left(\chi^{2}=5.8, \mathrm{df}\right.$ $=5 ; P=0.33$; RMSEA [root mean square error approximation] $=0.04$; CFI [comparative fit index] $=0.99$ ).

secondary cavity nesters (Fig. 3). In this model, large secondary cavity-nester nests are predicted by large cavity availability, which includes enlarged Red-cockaded Woodpecker cavities and large cavities in snags. We used Northern Flicker presence (sum of Northern Flicker nests and abundance) as a surrogate measure of Northern Flicker cavity excavation and enlargement behavior. Red-cockaded Woodpecker cavity availability is predicted by the abundance of Red-cockaded Woodpeckers (which excavate the original cavities) and Northern Flickers (which enlarge cavity entrances). Northern Flicker presence is predicted by pine snag availability. All links within the model were significant $(P<0.01)$, except for that between "Northern Flicker presence" and "Enlarged RCW cavities" $(P=0.069)$. The model explained $35 \%$ of the variation $\left(R^{2}\right)$ in large secondary cavity-nester nests and fit the observed data $\left(\chi^{2}=5.8, \mathrm{df}=5, P=0.33\right.$; RMSEA $=0.04 ; \mathrm{CFI}=0.99$; $\mathrm{AIC}=25.79)$. When we removed the nonsignificant link between "Northern Flicker presence" and "Enlarged RCW cavities," model fit was reduced $\left(\chi^{2}=9.0, \mathrm{df}=6, P\right.$ $=0.17$; $\mathrm{RMSEA}=0.07$; CFI $=0.97$; $\mathrm{AIC}=27.03)$. When we modified the model to include only pine snags $>20$ $\mathrm{cm}$ dbh (potential nest trees), the model fit to observed data improved $\left(\chi^{2}=5.0, \mathrm{df}=5, P=0.41 ;\right.$ RMSEA $<$ $0.01 ; \mathrm{CFI}=1.0 ; \mathrm{AIC}=25.03)$. In addition, the link between pine snags and Northern Flicker presence became significant at $P=0.001$, and the standardized partial regression coefficient for this link increased to 0.32 ; all other values in the model remained the same.

\section{Part 2: Experimental Study}

\section{Methods}

A concurrent experimental study enabled us to test the relationships shown in our path model. By using metal restrictor plates to repair existing enlarged Redcockaded Woodpecker cavities and prevent cavity enlargement by the Northern Flicker, we blocked two links within the model, including (1) the link between enlarged Red-cockaded Woodpecker cavities and Northern Flicker presence and (2) the link between enlarged Red-cockaded Woodpecker cavities and large secondary cavity nesters. We randomly selected eight plots for experimental manipulation along with eight control plots. Control and treatment plots did not differ significantly in the availability (mean \pm SD) of enlarged Red-cockaded Woodpecker cavities $(5.5 \pm 2.1$ and $7.9 \pm$ 3.4 , respectively; $t$ test, $t=1.7$, df $=14, P=0.11$ ) or pine snags $(23.8 \pm 16.6$ and $14.8 \pm 8.5$, respectively; $t$ test, $t=$ -1.36 , df $=14, P=0.20$ ) prior to experimental manipulation. Between September 2003 and January 2005, we installed metal restrictor plates on the entrances of all inactive and enlarged Red-cockaded Woodpecker cavities within experimental plots $(n=135$ cavities). Because our systematic protocol for nest searching began in 2003 and experimental treatments were completed after the 2004 season, the experimental portion of this study consists of 2003 (pre-treatment) and 2005 (post-treatment) data.

To control for annual variation, we used the amount of change in abundance and number of nests found in each plot between 2003 and 2005 to determine if there was a treatment effect. For each plot we subtracted pretreatment from post-treatment values and used a Mann Whitney $U$ test to detect significant differences in the amount of change between treatment and control plots. We predicted that the application of restrictors would cause a reduction Northern Flicker and southeastern American Kestrel abundance but that this effect would be weakened if snags were available as an alternative nesting resource. Because the Eastern Screech-Owl was rarely detected using our census methodology, we did not make predictions about their abundance. We predicted that the application of restrictors would cause a reduction in the number of large secondary cavitynester and Northern Flicker nests found in Red- 


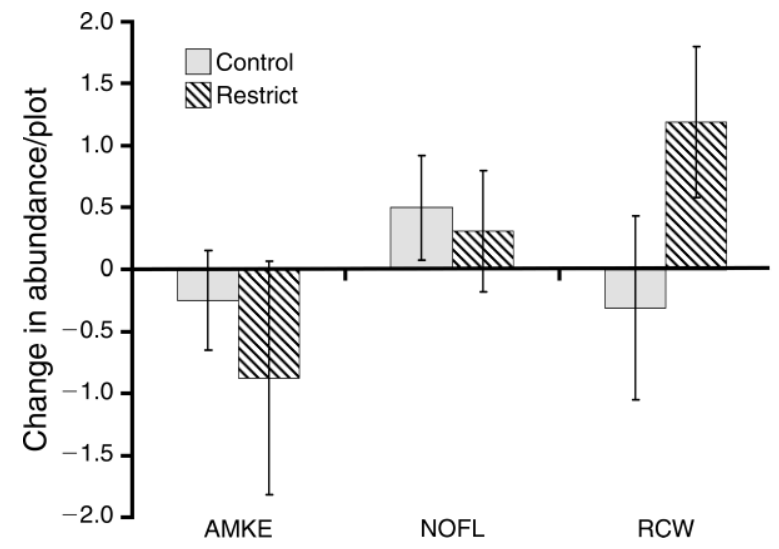

FIG. 4. Change (mean $\pm \mathrm{SE}$ ) in the abundance of the Northern Flicker (NOFL), Red-cockaded Woodpecker (RCW), and southeastern American Kestrel (AMKE) at Eglin Air Force Base in control (control, $n=8$ ) and experimental (restrict, $n=8$ ) plots from 2003 to 2005, following application of metal restrictor plates on RCW cavities.

cockaded Woodpecker cavities. For nest data analyses, both large secondary cavity-nesting species were grouped together. All data were analyzed using SAS, Version 9.1 (2003; SAS Institute, Cary, North Carolina, USA). Because our a priori predictions were directional, one-tailed tests were used, with a significance level of $P$ $<0.05$.

\section{Results of experimental study}

There was no difference between the change in Northern Flicker abundance in experimental and control plots $(U=70.5, P=0.42$; Fig. 4). Northern Flicker nests found in Red-cockaded Woodpecker cavities decreased in experimental plots, although not significantly more than in controls $(U=78, P=0.11$; Fig. 5). There was a significant increase in Northern Flicker nests found in snags in experimental plots $(U=$ 48.5, $P=0.01$ ) (Fig. 5), indicating a switch to the use of snags. Southeastern American Kestrel abundance decreased in experimental plots, although not significantly more than in controls $(U=71, P=0.40$; Fig. 4). There was a significant reduction in large secondary cavitynester nests found in Red-cockaded Woodpecker cavities $(U=89.5, P=0.01)$ in experimental plots (Fig. 6 ); however, there was no change in large secondary cavity-nester nests found in snags $(U=64.5, P=0.38$; Fig. 6). Finally, there was an increase in Red-cockaded Woodpecker abundance $(U=54.5, P=0.08)$, but no significant difference in number of Red-cockaded Woodpecker nests $(U=83, P=0.10)$ in experimental plots relative to controls.

\section{DisCUSSION}

Through the use of a nest web, structural equation modeling, and experimental manipulation, we identified the processes of cavity creation in living pine and enlargement of these cavities as mechanisms by which an indirect relationship arises between the Red-cockaded Woodpecker and large secondary cavity nesters. The use of metal restrictor plates to remove existing enlarged Red-cockaded Woodpecker cavities and hinder cavity enlargement behavior of the Northern Flicker resulted in a reduction of large secondary cavity-nester nests found in Red-cockaded Woodpecker cavities in living pine and caused the Northern Flicker to switch to snags for nesting. Pine snags were atypically abundant at Eglin during this study, ranging from 5.2 stems/ha to 8 stems/ha annually (Blanc 2007) and provided alternative nesting resources for cavity nesters; these nesting alternatives apparently buffered the impact of restrictor plates. The use of snags for nesting is contingent upon the ability to find existing cavities in snags or excavate new cavities. The Northern Flicker, capable of cavity excavation, has greater flexibility than secondary cavity nesters in switching to the use of available snags when Red-cockaded Woodpecker cavities are restricted. This flexibility seems to be reflected in our experimental results. These results suggest that Red-cockaded Woodpecker cavity creation and enlargement may be important processes within the longleaf pine ecosystem when snags are scarce.

The Red-cockaded Woodpecker indirectly improves the habitat of large secondary cavity nesters by influencing the excavation behavior of Northern Flickers. The presence of Red-cockaded Woodpecker cavities facilitates the ability of Northern Flickers to excavate in living pine, a behavior not found in forests where Redcockaded Woodpecker cavities are absent. This change in Northern Flicker excavation behavior enhances nesting habitat for large secondary cavity nesters, and thus, may cause an increase in large secondary cavitynester abundance. This interaction may be described as a trait-mediated indirect interaction in which one species (the Red-cockaded Woodpecker) indirectly affects the

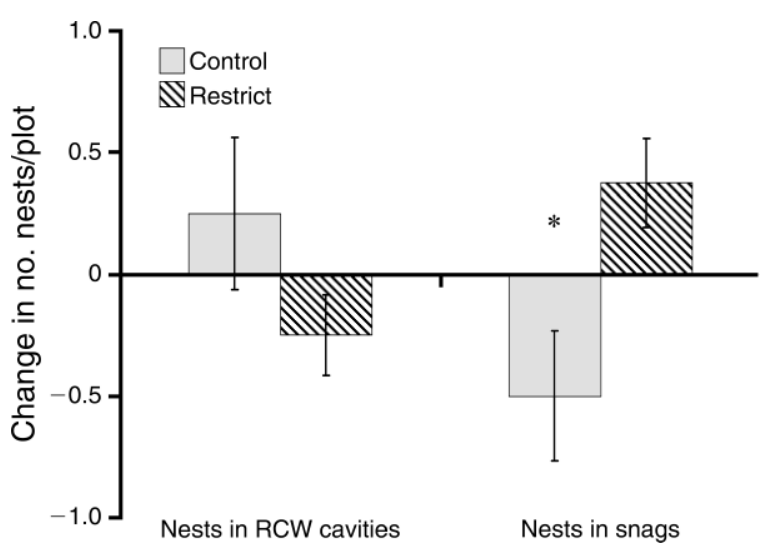

FIG. 5. Change (mean $\pm \mathrm{SE}$ ) in the number of Northern Flicker nests found in control (control, $n=8$ ) and experimental (restrict, $n=8$ ) plots from 2003 to 2005 , following application of metal restrictor plates on Red-cockaded Woodpecker $(\mathrm{RCW})$ cavities. An asterisk indicates a significant difference $(P<0.05)$ between control and experimental plots. 


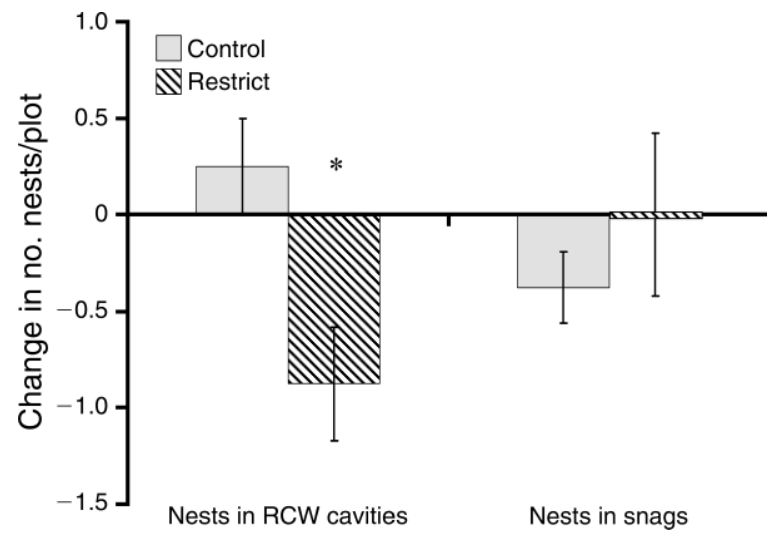

FIG. 6. Change (mean $\pm \mathrm{SE}$ ) in the number of large secondary cavity nester nests (southeastern American Kestrel and Eastern Screech-Owl) found in control (control, $n=8$ ) and experimental (restrict, $n=8$ ) plots from 2003 to 2005 following application of metal restrictor plates on Red-cockaded Woodpecker (RCW) cavities. An asterisk indicates a significant difference $(P<0.05)$ between control and experimental plots.

abundance of another species (large secondary cavity nesters) by altering the behavior of a third species (Northern Flicker) or by altering the environmental context of an interaction between two other species (a forest in which the Northern Flicker can excavate into living pine; Wootton 1993, Werner and Peacor 2003). In a recent review, Werner and Peacor (2003) argue that indirect interactions based on modification of traits (e.g., behavior) may be highly important and widespread phenomena within ecological communities, and in some cases, may have a greater influence on community dynamics and structure than indirect interactions based on modification of species densities. A better understanding of these complex community interactions and their underlying mechanisms can potentially improve our ability to predict community response to environmental change.

Our path model shows two pathways through which Red-cockaded Woodpeckers and Northern Flickers can create nesting habitat for large secondary cavity nesters. The first pathway represents the creation and enlargement of Red-cockaded Woodpecker cavities in living pine; the second pathway represents the creation of large cavities in pine snags. We propose that retaining snags in southern pine forests, particularly snags of sufficient diameter for nesting by large species, can ensure that the second pathway of the model remains intact (large pine snags $\rightarrow$ Northern Flicker presence $\rightarrow$ large secondary cavity-nester nests). Maintaining this pathway may mitigate potential negative impacts of metal restrictor plates on large secondary cavity nesters, particularly in small, managed Red-cockaded Woodpecker populations where restrictor plates may be critical to the maintenance of a limited number of cavities.

This study provides an empirical example of how, in ecological communities where complex species interac-
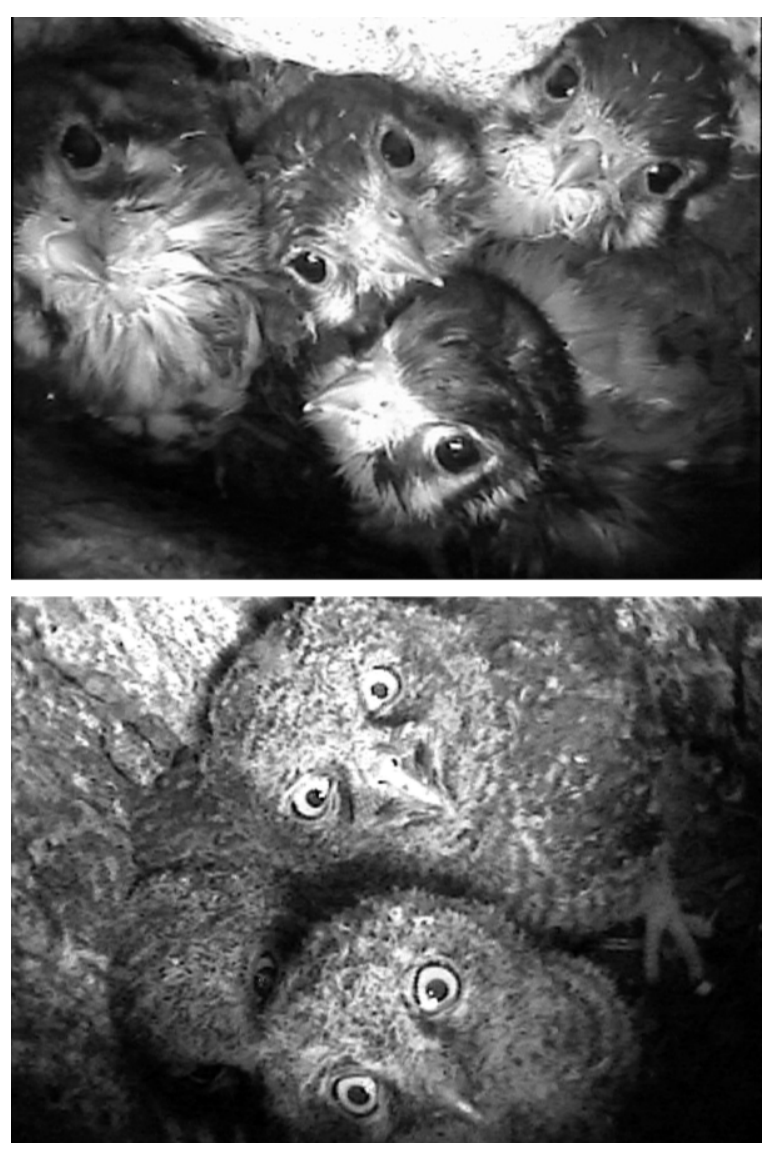

Plate 1. (Top) Four of five Southeastern American Kestrel nestlings found in a cavity originally excavated by a Northern Flicker in a longleaf pine snag. (Bottom) Three Eastern Screech-Owl nestlings in a cavity originally excavated by a Red-cockaded Woodpecker. Photo credits: L. Blanc.

tions occur, single-species management can have indirect impacts on non-target species. In some cases, these indirect effects may have broader implications for conservation management. For example, the southeastern American Kestrel, which was indirectly affected by the use of metal restrictor plates in this study, is listed as threatened in the state of Florida, USA (Wood 1996). In addition, Simberloff (1998) suggested that metal restrictor plates may impact the declining Sherman's fox squirrel (Sciurus niger shermani). Negative impacts of Red-cockaded Woodpecker cavity management on these declining species may conflict with ecosystem management goals of the Endangered Species Act of 1973. Understanding the mechanisms or processes that create suitable habitat for a broad suite of species within a larger associated community may ultimately improve our ability to effectively design conservation management strategies (Paine 1995, Simberloff 1998, Soulé et al. 2003). Indeed, Soulé et al. (2003) propose that biodiversity conservation should include the protection of critical interspecific interactions, a goal that necessitates the integration of theoretical ecology into conservation 
management strategies (e.g., Walters 1991). In this study, we demonstrate how a study of basic ecological principles can inform conservation management and concomitantly, how the application of a management technique can aid in the study of basic ecological principles.

Because tree cavities serve as roosting and nesting habitat for a broad range of birds, mammals, herpetofauna, and insects, the process of cavity creation may serve as a mechanism that influences community structure in forests worldwide. Woodpeckers have long been recognized as an important component of forest ecosystems (Virkkala 2006) and may be used as general indicators of forest biodiversity (Mikusiński et al. 2001). The structured, nest-web characteristic of cavity-nesting communities makes them well suited for studies of complex community interactions because mechanisms that structure these communities seem to be clear and testable through experimental manipulation (e.g., see Aitken and Martin 2008). The experimental study presented here is the first demonstration of how cavity manipulation can be used to test inferred processes derived from a nest web. The findings presented here highlight the need to develop a better understanding of how mechanisms underlying species interactions can influence community structure and ultimately mitigate or exacerbate community responses to future changes in environmental conditions.

\section{ACKNOWLEDGMENTS}

Funding for this study was provided by D.O.D. Threatened and Endangered Species funds from Eglin Air Force Base, a National Science Foundation Doctoral Dissertation Improvement Grant (0508656), and grants from Sigma Xi, Florida Ornithological Society, WPI International, PEO International, and the Virginia Tech Graduate Research Development Program. We are grateful to personnel from Jackson Guard at Eglin for their assistance with this study. We thank the field crews who assisted with data collection, including M. Anderson, L. Brock, M. Colón, R. Emerson, S. Gibson, J. Kolts, K. Kubala, K. Rose, and B. Orning-Tschampl. Experimental manipulation and valuable logistical support were provided by K. Gault, J. Kowalsky, L. Oztolaza, A. Butler, and L. Phillips. We thank L. Adler, C. Haas, R. Jones, and D. Stauffer for their input throughout this study. Finally, we thank J. Bednarz and an anonymous reviewer for helpful comments on earlier drafts of this manuscript.

\section{Literature Cited}

Aitken, K., and K. Martin. 2008. Plasticity in resource selection affects community responses to an experimental reduction in availability of a critical resource. Ecology 89:971-980.

Akaike, H. 1987. Factor analysis and AIC. Psychometrika 52: 317-332.

Allen, D. H. 1991. Constructing artificial red-cockaded woodpecker cavities. U.S. Department of Agriculture Forest Service Technical Report SE-73, Washington, D.C., USA.

Allen, J. C., S. M. Krieger, J. R. Walters, and J. A. Collazo. 2006. Associations of breeding birds with fire-influenced and riparian-upland gradients in a longleaf pine ecosystem. Auk 123:1110-1128.

Bednarz, J. C., D. Ripper, and P. M. Radley. 2004. Emerging concepts and research directions in the study of cavitynesting birds: keystone ecological processes. Condor 106:1-4.
Bentler, P. M. 1990. Comparative fit indices in structural models. Psychological Bulletin 107:238-246.

Bibby, C. J., N. D. Burgess, and D. A. Hill. 1992. Bird census techniques. Academic Press, San Diego, California, USA.

Blanc, L. A. 2007. Experimental study of an avian cavitynesting community: nest webs, nesting ecology, and interspecific interactions. Ph.D. dissertation, Virginia Polytechnic Institute and State University, Blacksburg, Virginia, USA.

Blanc, L. A., and J. R. Walters. 2007. Cavity-nesting community webs as predictive tools: Where do we go from here? Journal of Ornithology 148:417-423.

Blanc, L. A., and J. R. Walters. 2008. Cavity-nest webs in a longleaf pine ecosystem. Condor, in press.

Burns, C. E., K. M. Johnston, and O. J. Schmitz. 2003. Global climate change and mammalian species diversity in U.S. national parks. Proceedings of the National Academy of Sciences (USA) 100:11474-11477.

Carter, J. H., III, J. R. Walters, S. H. Everhart, and P. D. Doerr. 1989. Restrictors for Red-cockaded Woodpecker cavities. Wildlife Society Bulletin 17:68-72.

Conner, R. N., D. C. Rudolph, and J. R. Walters. 2001. The Red-cockaded Woodpecker: surviving in a fire-maintained ecosystem. University of Texas Press, Austin, Texas, USA.

Conner, R. N., C. E. Shackelford, R. R. Schaefer, D. Saenz, and D. C. Rudolph. 2002. Avian community response to southern pine ecosystem restoration for Red-cockaded Woodpeckers. Wilson Bulletin 114:324-332.

Copeyon, C. K. 1990. A technique for constructing cavities for the Red-cockaded Woodpecker. Wildlife Society Bulletin 18: 303-311.

Copeyon, C. K., J. R. Walters, and J. H. Carter. 1991. Induction of Red-cockaded Woodpecker group formation by artificial cavity construction. Journal of Wildlife Management 55:549-556.

Grace, J. B. 2006. Structural equation modeling and the study of natural systems. Cambridge University Press, Cambridge, UK.

Grace, J. B., and B. H. Pugesek. 1998. On the use of path analysis and related procedures for the investigation of ecological problems. American Naturalist 152:151-159.

Hutto, R. L., S. M. Pletschet, and P. Hendricks. 1986. A fixedradius point count method for nonbreeding and breeding season use. Auk 103:593-602.

Kappes, J. J. 2004. Community interactions associated with Red-cockaded Woodpecker cavities. Pages 458-467 in R. Costa and S. J. Daniels, editors. Red-cockaded Woodpecker: road to recovery. Hancock House Publishers, Blaine, Washington, USA.

Kareiva, P. M., J. G. Kingsolver, and R. B. Huey. 1993. Biotic interactions and global change. Sinauer Associates, Sunderland, Massachusetts, USA.

Kindell, C. E., B. J. Herring, C. Nordman, J. Jensen, A. R. Schotz, and L. G. Chafin. 1997. Natural community survey of Eglin Air Force Base, 1993-1996: final report. Florida Natural Areas Inventory, Tallahassee, Florida, USA.

Kline, R. B. 1998. Principles and practice of structural equation modeling. Guilford Press, New York, New York, USA.

Krebs, C. J. 1994. Ecology: the experimental analysis of distribution and abundance. Fourth edition. Harper-Collins, New York, New York, USA.

Litt, A. R., L. P. Provencher, G. W. Tanner, and R. Franz. 2001. Herpetofaunal responses to restoration treatments of longleaf pine sandhills in Florida. Restoration Ecology 9: $462-474$.

Martin, K., and J. M. Eadie. 1999. Nest webs: a communitywide approach to management and conservation of cavitynesting forest birds. Forest Ecology and Management 115: 243-257.

McWhite, R. W., J. Furman, C. J. Petrick, and S. M. Sieber. 1999. Integrated natural resources transitional plan, Eglin 
Air Force Base, 1998-2001. Jackson Guard, Niceville, Florida, USA.

Menge, B. A. 1995. Indirect effects in marine rocky intertidal interaction webs: patterns and importance. Ecological Monographs 65:21-74.

Mikusiński, G., M. Gromadzki, and P. Chylarecki. 2001. Woodpeckers as indicators of forest bird diversity. Conservation Biology 15:208-217.

Paine, R. T. 1980. Food webs: linkage, interaction strength and community infrastructure. Journal of Animal Ecology 49: 667-685.

Paine, R. T. 1995. A conversation on refining the concept of keystone species. Conservation Biology 4:962-964.

Parmesan, C., and H. Galbraith. 2004. Observed impacts of global climate change in the U.S. Pew Center on Global Climate Change, Arlington, Virginia, USA.

Parmesan, C., and G. Yohe. 2003. A globally coherent fingerprint of climate change impacts across natural systems. Nature 421:37-42.

Provencher, L., N. M. Gobris, L. A. Brennan, D. R. Gordon, and J. L. Hardesty. 2002. Breeding bird response to midstory hardwood reduction in Florida sandhill longleaf pine forests. Journal of Wildlife Management 66:641-661.

Provencher, L., B. J. Herring, D. R. Gordon, H. L. Rodgers, K. E. M. Galley, G. W. Tanner, J. L. Hardesty, and L. A. Brennan. 2001. Effects of hardwood reduction techniques on longleaf pine sandhill vegetation in northwest Florida. Restoration Ecology 9:13-27.

Pugesek, B. H., and J. B. Grace. 1998. On the utility of path modeling for ecological and evolutionary studies. Functional Ecology 12:843-856.

Raulston, B. E., D. A. James, and J. E. Johnson. 1996. Effects of cavity-entrance restrictors on Red-cockaded Woodpeckers. Wildlife Society Bulletin 24:694-698.

Simberloff, D. 1998. Flagships, umbrellas, and keystones: is single-species management passé in the landscape era? Biological Conservation 83:247-257.

Soulé, M. E., J. E. Estes, J. Berger, and C. M. del Rio. 2003. Ecological effectiveness: conservation goals for interactive species. Conservation Biology 17:1238-1250.

Stachowicz, J. J. 2001. Mutualism, facilitation and the structure of ecological communities. BioScience 51:235-246.

Strauss, S. Y. 1991. Indirect effects in community ecology: their definition, study and importance. Trends in Ecology and Evolution 6:206-210.

USFWS. 2003. Recovery plan for the Red-cockaded Woodpecker (Picoides borealis), second revision. U.S. Department of the Interior, Fish and Wildlife Service, Atlanta, Georgia, USA.
Varner, J. M., D. R. Gordon, F. E. Putz, and J. K. Hiers. 2005. Restoring fire to long-unburned Pinus palustris ecosystems: novel fire effects and consequences for long-unburned ecosystems. Restoration Ecology 13:1-9.

Varner, J. M., and J. S. Kush. 2001. Old-growth longleaf pine forests - filling in the blanks. Pages 204-208 in J. S. Kush, editor. Proceedings of the Third Longleaf Alliance Conference. The Longleaf Alliance, Auburn, Alabama, USA.

Virkkala, R. 2006. Why study woodpeckers? The significance of woodpeckers in forest ecosystems. Annales Zoologici Fennici 43:82-85.

Walters, J. R. 1991. Application of ecological principles to the management of endangered species: the case of the Redcockaded Woodpecker. Annual Review of Ecology and Systematics 22:505-523.

Walters, J. R., J. H. Carter III, and P. D. Doerr. 2004. Population dynamics of Red-cockaded Woodpeckers and cavity kleptoparasites: implications of cavity experiments in the North Carolina Sandhills. Pages 468-479 in R. Costa and S. J. Daniels, editors. Red-cockaded Woodpecker: road to recovery. Hancock House Publishers, Blaine, Washington, USA.

Walther, G. R., E. Post, P. Convey, A. Menzel, C. Parmesan, T. J. C. Beebee, J. M. Fromentin, O. Hoegh-Guldberg, and F. Bairlein. 2002. Ecological responses to recent climate change. Nature 416:389-395.

Werner, E. E., and S. D. Peacor. 2003. A review of traitmediated indirect interactions in ecological communities. Ecology 84:1083-1100.

Wood, D. A. 1996. Florida's endangered species, threatened species and species of special concern. Bureau of Nongame Wildlife. Florida Game and Freshwater Fish Commission, Tallahassee, Florida, USA.

Wood, D. R., L. W. Burger, F. J. Vilella, and B. E. Raulston. 2000. Long-term effects of Red-cockaded Woodpecker cavity-entrance restrictors. Wildlife Society Bulletin 28:105109.

Wootton, J. T. 1993. Indirect effects and habitat use in an intertidal community: interaction chains and interaction modifications. American Naturalist 141:71-89.

Wootton, J. T. 1994a. Predicting direct and indirect effects: an integrated approach using experiments and path analysis. Ecology 75:151-165.

Wootton, J. T. 1994b. The nature and consequences of indirect effects in ecological communities. Annual Review of Ecology and Systematics 25:443-466.

Wootton, J. T. 2002. Indirect effects in complex ecosystems: recent progress and future challenges. Journal of Sea Research 48:157-172. 